\title{
Nutrient control of estuarine macroalgae: growth strategy and the balance between nitrogen requirements and uptake
}

\author{
Morten Foldager Pedersen*, Jens Borum \\ Freshwater-Biological Laboratory, University of Copenhagen, Helsingorsgade 51, DK-3400 Hillerod, Denmark
}

\begin{abstract}
The ability to sustain growth at low availability of nitrogen (N) was examined in 6 species of macroalgae with different growth strategies by compdring substrate dependent growth kinetics. The $\mathrm{N}$ required to support optimal growth and the $\mathrm{N}$ uptake kinetics of 2 slow-growing algae, Fucus vesiculosus and Codium fragile, and 4 fast-growing species, Chatomorpha linum, Cladophora serica, Ceramium rubrum and Ulva lactuca, were experimentally determined in summer when the algae were $\mathrm{N}$ limited. The $\mathrm{N}$ required to support maximum growth varied 16 -fold among species, with fast-growing algae having the highest $\mathrm{N}$ demands. The high $\mathrm{N}$ requirements of ephemeral algae were caused by up to 13 -fold higher growth rates and 2 - to 3 -fold higher $N$ content at maximum growth. Also, the fastgrowng species took up ammonium and nitrate 4 to 6 times faster per unit of biomass than slow-growing species at both low and high substrate concentrations, but the ratios of maximum $\mathrm{N}$ uptake to requirements were larger among the slow-growing algae. Thus, the fast-growing species tended to require relatively higher external concentrations of inorganic $N$ to saturate their growth. Under $N$ limited conditions, all 6 macroalgae were able to exploit pulses of high concentrations of ammonium by taking up ammonium at transiently enhanced rates (i.e. surge uptake). Uptake was, however, only marginally enhanced at low, and naturally occurring, concentrations of ammonium, suggesting that surge uptake is of minor ecological importance. Our results show that large, slow-growing macroalgae may be better able to meet their $\mathrm{N}$ requirements at low $\mathrm{N}$ availability than fast-growing species. This is consistent with the common observation that nutrient-poor coastal areas are dominated by slowgrowing macroalgae rather than ephemeral species, although ephemeral species have higher $\mathrm{N}$ uplake capacities.
\end{abstract}

KEY WORDS: Marine macroalgae Nitrogen requirement Nitrogen uptake Competition

\section{INTRODUCTION}

Nutrient availability is an important factor controlling plant performance and species composition of plant communities in shallow coastal waters (Borum 1983, Orth \& Moore 1983, Twilley et al. 1985, Neundorfer \& Kemp 1993, Taylor et al. 1995, Borum 1996). These shallow water plant communities are composed of a large number of species representing various growth strategies and life forms, and the contribution

- Present address: Department of Life Sciences and Chemistry 17.2, Roskilde University Center, Box 260, DK-4000 Roskilde, Denmark. E-mail: mfp@virgil.ruc.dk of the different plant types to total autotrophic biomass and production is regulated by several factors that influence growth and loss processes (Sand-Jensen \& Borum 1991. Duarte 1995). The distribution of macroalgae along nutrient gradients is typically characterized by slow-growing species in nutrient-poor regions or seasons, while fast-growing, ephemeral species dominate under nutrient-rich conditions (Kautsky et al. 1986, Sfriso et al. 1987, Ménesguen \& Piriou 1995, Taylor et al. 1995, Borum \& Sand-Jensen 1996)

The association between high nutrient availability and increased dominance of ephemeral macroalgae suggests that fast-growing species require high nutrjent inputs to sustain growth, while large, slow-grow- 
ing species are better adapted to nutrient-poor conditions. In support of this idea, Pedersen \& Borum (1996) demonstrated that ephemeral macroalgae suffered from $\mathrm{N}$ limitation during longer periods of low $\mathrm{N}$ availability in summer than did slow-growing species. The observed variation in $\mathrm{N}$ limitation among algae of different growth strategy could partly be explained by species-specific differences in $\mathrm{N}$ requirements and storage capacity. However, the work also indicated that, compared to ephemeral species, slow-growing macroalgae were better able to meet their $\mathrm{N}$ requirements by exploiting low external $N$ concentrations (Pedersen \& Borum 1996).

Ephemeral macroalgae with thin thalli and simple morphology take up $\mathrm{N}$ faster per unit of biomass and, further, have higher affinities for uptake at low $\mathrm{N}$ concentrations than large, slow-growing species (Wallentinus 1984, Fujita 1985, Hein et al. 1995). Fast $N$ uptake and high affinity among ephemeral algae has formerly been used to imply that these algae were well suited to compete for nutrients at low availability of $\mathrm{N}$ It has also been hypothesized that ephemeral species utilize short-term pulses of ammonium by taking it up at transiently enhanced rates (i.e. surge uptake), thereby compensating for low uptake during subsequent periods of low $N$ availability (Fujita 1985). Surge uptake has been documented for a large number of macroalgae (e.g. Fujita 1985, Thomas \& Harrison 1987. Harrison et al. 1989, Pedersen 1994, McGlathery et al. 1996), and McGlathery et al. (1996) showed that the length and magnitude of the surge uptake were inversely related to the size of intracellular pools of ammonium in the ephemeral macroalga Chaetomorpha linum. If this mechanism is a general feature among algae, we expect all algal species to be able to perform surge uptake independently of growth strategy.

The advantage of fast uptake at low availability of $\mathrm{N}$ gained by ephemeral algae may, however, be offset if the $N$ requirements of these species are comparably higher than the requirements for large, slow-growing species. The only way to evaluate species-specific differences in sensitivity to nutrient stress is to combine the kinetics for $\mathrm{N}$ uptake and $\mathrm{N}$ dependent growth into substrate dependent growth kinetics (Dugdale 1967) and then compare the ability of different species to sustain growth at low substrate concentrations (Turpin 1988).

The objective of this study was to test the hypothesis that large, slow-growing macroalgae are better adapted to grow under low $\mathrm{N}$ availability than fastgrowing, ephemeral species, because their $\mathrm{N}$ requirements and uptake of $N$ are better balanced at potentially limiting $N$ concentrations. We addressed this question by comparing substrate dependent growth $\mathrm{ki}$ netics, modeled from experimentally determined kinet- ics of $N$ uptake and $N$ requirements for growth among 6 species of macroalgae with inherently different maximum growth rates. We also tested whether the presence and magnitude of surge uptake differed significantly between fast- and slow-growing macroalgae.

\section{METHODS}

Whole thalli of 6 macroalgal species with different growth strategies were collected in Roskilde Fjord, Denmark, during late July and August 1991, when the algae were $N$ limited (Pedersen 1995, Pedersen \& Borum 1996). Fucus vesiculosus L. and Codium fragile (Suringar) Hariot. Lucas are slow-growing, perennial macroalgae with thick and structurally complex thalli, while Ulva lactuca L., Cladophora serica (Huds.) Lhtz., Chaetomorpha linum (O.F Müll.) Lhtz. and Ceraminm rubrum (Huds.) C.Ag, are annual species having thin thalli and high maximum growth rates. The algae were rinsed of sediment, debris and epiphytes and kept in laboratory cultures for 5 to $7 \mathrm{~d}$ before being used for assessment of $\mathrm{N}$ requirements for growth or for uptake experiments. The culture tanks contained freshly collected water from the sampling site [salinity $=17 \%$; dissolved inorganic $N$ (DIN) $<1 \mu \mathrm{M}$; dissolved inorganic $\mathrm{P}$ (DIP) $=4$ to $6 \mu \mathrm{M}$ ] and were kept at constant irradiance $\left(300 \mu \mathrm{mol} \mathrm{m} \mathrm{m}^{-2} \mathrm{~s}^{-1} \mathrm{PAR}\right.$ in a $16 \mathrm{~h}$ light: $8 \mathrm{~h}$ dark cycle) and temperature $\left(15^{\circ} \mathrm{C}\right)$

Nitrogen dependent growth. Data for growth of Fucus vesiculosus, Ulva lactuca, Ceramium rubrum, Chaetomorpha linum and Cladophora serica as functions of internal $\mathrm{N}$ contents in the algal tissues were obtained from Pedersen \& Borum (1996), while $N$ dependent growth of Codium fragile was experimentally determined in the present study, using the same method as in Pedersen \& Borum (1996). All 6 species of macroalgae were grown in laboratory cultures under constant light $\left(300 \mu \mathrm{mol} \mathrm{m} \mathrm{m}^{-2} \mathrm{~s}^{-1}\right.$ PAR in a $16 \mathrm{~h} \mathrm{light:} 8 \mathrm{~h}$ dark cycle) and temperature $\left(15^{\circ} \mathrm{C}\right)$. Nitrogen loadings were varied to obtain specimens with a range of different tissue $N$ concentrations. Growth rates $(\mu)$ were measured as the increase in biomass assuming exponential growth:

$$
\mu=\left(\ln B_{1}-\ln B_{0}\right) /\left(T_{1}-T_{0}\right)
$$

where $B_{0}$ and $B_{l}$ are the dry weight biomass of algae at the beginning $\left(T_{0}\right)$ and at the end $\left(T_{t}\right)$ of the experimental period. Observed growth rates were plotted against tissue $\mathrm{N}$ concentrations $(\mathrm{N}$ ) and the Droop equation (Droop 1983) was fitted to the data using nonlinear, least squares regression:

$$
\mu=\mu_{\max }\left[1-\left(\mathrm{N}_{\mathrm{Q}} / \mathrm{N}\right)\right]
$$

where $\mu_{\max }$ is the maximum growth rate at infinite 
tissue $\mathrm{N}$ concentrations, $\mathrm{N}_{Q}$ is the minimum tissue $\mathrm{N}$ content needed to sustain growth (the subsistence $N$ quota), and $\mathrm{N}$ is the actual tissue $\mathrm{N}$ concentration. The critical $\mathrm{N}$ concentration $\left(\mathrm{N}_{\mathrm{C}}\right.$ ) needed to sustain growth at maximum rates was estimated as the intercept between the initial slope of the curve and the maximum growth rate $\left(\mu_{\max }\right)$, while $\mathrm{N}$ requirements for maximum growth $\left(\mathrm{N}_{\text {req }}\right.$ ) were estimated as the product of the maximum growth rate and critical $N$ concentration (i.e. $\mu_{\max } \times \mathrm{N}_{\mathrm{c}}$ )

Uptake experiments. Uptake of ammonium may initially be enhanced and nitrate uptake suppressed, when $N$ depleted algae are exposed to sudden pulses of inorganic N (McGlathery et al. 1996). To discern the different phases of $\mathrm{N}$ uptake, we measured uptake rates of ammonium and nitrate by several time-course depletion experiments, lasting 4 to $10 \mathrm{~h}$ each. The depletion of substrate due to uptake was measured over different time intervals and substrate concentrations in each experiment, so that any transient phases appearing during the initial stage of the experiments could be separated from the more constant uptake rates occurring subsequently (referred to as 'assimilation rates', for details see Pedersen 1994, McGlathery et al. 1996)

The uptake experiments were carried out in translucent plexiglas chambers containing $2 \mathrm{l}$ of medium and kept under constant irradiance $\left(400 \mu \mathrm{mol} \mathrm{m} \mathrm{m}^{-2} \mathrm{~s}^{-1}\right.$ PAR) and temperature $\left(15^{\circ} \mathrm{C}\right)$. Water circulation was generated by submersible pumps $\left(61 \mathrm{~min}^{-1}\right)$. Filtered (Whatman $G F / C$ ) seawater was enriched with $\mathrm{N}$ by adding either $\mathrm{NH}_{4} \mathrm{Cl}$ or $\mathrm{NaNO}_{3}$ from stock solutions. The uptake experiments were carried out with at least 6 different starting concentrations of $\mathrm{N}$, ranging from 3.5 to $85 \mu \mathrm{M}$ ammonium or from 3.5 to $45 \mu \mathrm{M}$ nitrate. Algal material ( 0.1 to $0.7 \mathrm{~g} \mathrm{DW})$ was fixed on a Nitex mesh and submersed in the medium at time $t=0$. Triplicate water samples $(5 \mathrm{ml})$ were collected every $15 \mathrm{~min}$ during the first $90 \mathrm{~min}$ and subsequently every $30 \mathrm{~min}$ until all inorganic $N$ had been depleted from the medium (within 240 to $600 \mathrm{~min}$ ). Ammonium was immediately analyzed using the phenol-hypochlorite method (Solórzano 1969), while nitrate samples were frozen for later analysis on an Alpha Chem ${ }^{(}$Auto Analyzer. Algal dry weight was determined after drying to constant weight at $90^{\circ} \mathrm{C}$ for $48 \mathrm{~h}$

Uptake rates [V ( $\left.\left.\mu \mathrm{mol} \mathrm{g}^{-1} \mathrm{DW} \mathrm{h}^{-1}\right)\right]$ were calculated for each time interval during the depletion according to:

$$
V=\left[\left(S_{0} \times \operatorname{vol}_{0}\right)-\left(S_{1} \times \operatorname{vol}_{t}\right)\right] /(t \times B)
$$

where $S_{0}$ and $S_{1}$ are the substrate concentrations and $\mathrm{vol}_{0}$ and vol, the volumes before and after a sampling period $(t)$, and $B$ is algal dry weight biomass. Uptake rates $(V)$ were plotted against the mean substrate con- centration $(S)$ for each time interval, and the MichaelisMenten function was fitted to the data using nonlinear, least squares regression:

$$
V=\left(V_{\max } \times S\right) /\left(K_{\mathrm{m} 1}+S\right)
$$

where $V_{\max }$ is the maximum uptake rate and $K_{\mathrm{m}}$ the half-saturation constant for uptake. The initial slope of the $V$ versus $S$ curve, equal to $V_{\max } / K_{\mathrm{m}}$, was calculated and used as an index of $N$ uptake affinity at low substrate concentrations (Healy 1980).

Estimation of substrate dependent growth. The association between growth rate and the concentration of ammonium or nitrate in the water was estimated for each species using the uptake kinetics (Eq. 4) for either ammonium (the 'assimilation' kinetics) or nitrate and the relationship between growth rate and tissue $\mathrm{N}$ content (Eq. 2), assuming steady state conditions. The relation between growth rate and substrate concentration under steady state conditions can be described by a Monod type equation:

$$
\mu=\left(\mu_{\max } \times S^{*}\right) /\left(K_{\mu}+S^{*}\right)
$$

where $\mu^{*}: \ldots$ ix the maximum growth rate under steadystate conditions, $K_{u}$ is the half-saturation constant for growth, and $S^{*}$ is the steady-state substrate concentration. Eqs. (2) \& (4) can be combined and solved for $N_{Q}$. which is then substituted into Eq. (2) to estimate the constants $\mu^{\circ}{ }_{\max }$ and $K_{\mu}$ of Eq. (5). Turpin (1988) provide a detailed description for the derivation of the equations defining $\mu^{*}$ max and $K_{u}$ :

$$
\mu_{\max }^{*}=\left(\mu_{\max } \times V_{\text {mix }}\right) /\left[\left(\mu_{\max } \times N_{Q}\right)+V_{\max }\right]
$$

and

$$
K_{\mu}=\left(K_{\mathrm{m}} \times \mu_{\max } \times \mathrm{N}_{Q}\right) /\left[\left(\mu_{\max } \times \mathrm{N}_{\mathrm{Q}}\right)+V_{\max }\right]
$$

where $V_{\max }, K_{\mathrm{m}}, \mu_{\max }$ and $\mathrm{N}_{Q}$ are defined as described for Eqs. (2) \& (4). Both $\mu^{*}$ max and $K_{\mu}$ of Eq. (5) were estimated from measured values of $V_{\max }, K_{\mathrm{m}}, \mu_{\max }$ and $\mathrm{N}_{\mathrm{Q}}$. and used to model growth rates at typical in situ concentrations of ammonium and nitrate, respectively. The computation was performed assuming no effects of stored $\mathrm{N}$ in the algae.

Error estimation. The substrate dependent growth rate $\left(\mu^{*}\right)$ and the half-saturation constant for growth $\left(K_{\mu}\right)$ were both calculated as combinations of several individual variables, each measured with their own error. The bootstrap procedure (Efron \& Tibshirani 1986) was, therefore, applied to estimate means and confidence limits for the combined results. All the individual variables were assumed to be normally distributed with observed means and standard deviations. Bias-adjusted bootstrapped mean values $\left(\bar{x}_{B, \text { adj }}\right)$ of $\mu^{*}$ max and $K_{\mu}$ were computed from the individual variables (Eqs. 6 \& 7) using Monte Carlo resampling (100 mean values were estimated), according to Meyer 
et al. (1986). Bias-adjusted $95 \%$ confidence limits were finally computed from the 2.5 and $97.5 \%$ percentiles of the bootstrapped data sets following the procedure presented by Meyer et al. (1986).

\section{RESULTS}

\section{Nitrogen requirements}

Maximum growth rates $\left(\mu_{\max }\right)$, subsistence quotas $\left(N_{Q}\right)$ and critical tissue $N$ concentrations $\left(N_{C}\right)$ obtained in the laboratory experiments (this study and Pedersen \& Borum 1996) are summarized in Table 1. In general, growth rates increased as functions of tissue $\mathrm{N}$ concentration as exemplified by the relationship between growth and tissue $\mathrm{N}$ in Codium fragile (Fig, 1). The maximum growth rate at infinite tissue $N$ concentration varied 13-fold among species and was lowest for Fucus vesiculosus and $C$. fragile $\left(0.039\right.$ and $\left.0.083 \mathrm{~d}^{-1}\right)$ and highest among the 4 ephemeral species $(0.218$ to $0.513 \mathrm{~d}^{-1}$; Table 1).

The subsistence quota $\left(\mathrm{N}_{\mathrm{Q}}\right)$ ranged from $0.38 \% \mathrm{~N}$ of DW in Chaetomorpha linum to $1.02 \%$ of DW in Ceramium rubrum, with the remaining values being clustered around $0.6 \% \mathrm{~N}$ of DW. The critical tissue $\mathrm{N}$

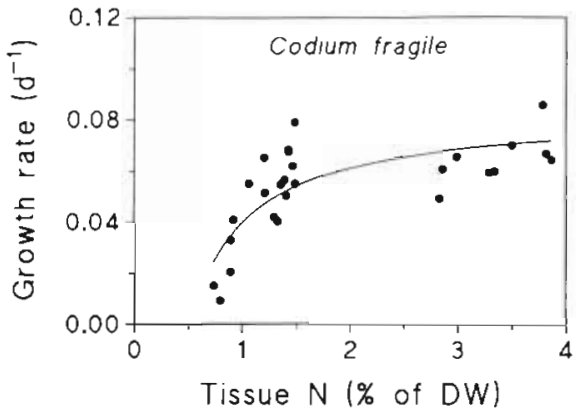

Fig. 1 Codium fraglle. Relationship between growth rate and tissue $\mathrm{N}$ concentration as determined in laboratory experiments

concentration $\left(\mathrm{N}_{\mathrm{C}}\right)$ ranged from $1.15 \% \mathrm{~N}$ of DW in $C$. linum to $3.1 \% \mathrm{~N}$ of DW in C. rubrum (Table 1). Both $N_{Q}$ and $N_{C}$ tended to increase with increasing maximum growth rate of the algal species, but the patterns were not consistent since $N_{Q}$ and $N_{C}$ were low for the relatively fast-growing $C$. linum. The amount of $N$ required to sustain maximum algal growth varied 16-fold, from $48 \mu \mathrm{mol} \mathrm{N} \mathrm{g} \mathrm{NW} \mathrm{d}^{-1}$ in Fucus vesiculosus to $795 \mu \mathrm{mol} \mathrm{N} \mathrm{g}^{-1} \mathrm{DW} \mathrm{d}^{-1}$ in Ulva lactuca (Table 1).

Table 1 Maximum growth rates $\left(\mu_{\max }\right)$, subsistence quotas $\left(\mathrm{N}_{Q}\right)$, critical tissue $\mathrm{N}$ concentrations $\left(\mathrm{N}_{\mathrm{C}}\right)$ and estimated $\mathrm{N}$ requirements for growth under laboratory conditions in 6 species of macroalgae. Estimates of $\mu_{\max }$ and $\mathrm{N}_{Q}$ were obtained by non-linear least squares regression. Numbers are mean values with $95 \%$ confidence intervals in parentheses. Data for all algae except for Codium fragile are from Pedersen \& Borum (1996)

\begin{tabular}{|lcccc|}
\hline & $\mu_{\max }\left(\mathrm{d}^{-1}\right)$ & $\mathrm{N}_{\mathrm{Q}}(\% \mathrm{~N}$ of DW & $\mathrm{N}_{\mathrm{C}}(\% \mathrm{~N}$ of DW $)$ & $\mathrm{N}_{\text {req }}\left(\mu \mathrm{mol} \mathrm{N} \mathrm{N}^{-1} \mathrm{DW} \mathrm{\textrm {d } ^ { - 1 } )}\right.$ \\
\hline Fucus vesiculosus & $0.039(0.003-0.127)$ & $0.55(0.35-0.64)$ & $1.71(-1.48-4.38)$ & $48(-95-219)$ \\
Codium fragile & $0.083(0.072-0.094)$ & $0.52(0.40-0.64)$ & $1.58(0.45-2.61)$ & $96(25-169)$ \\
Chaetomorpha linum & $0.218(0.176-0.260)$ & $0.38(0.37-0.39)$ & $1.15(0.96-1.38)$ & $179(143-229)$ \\
Cladophora serica & $0.251(0.189-0.313)$ & $0.68(0.57-0.79)$ & $2.05(0.93-3.31)$ & $364(157-607)$ \\
Ceramium rubrum & $0.223(0.176-0.270)$ & $1.02(0.97-1.08)$ & $3.10(2.59-3.64)$ & $493(379-614)$ \\
Ulva lactuca & $0.513(0.479-0.547)$ & $0.71(0.66-0.76)$ & $2.17(1.33-2.93)$ & $795(595-987)$ \\
\hline
\end{tabular}

Table 2. Nitrogen uptake kinetics. The kinetic parameters $V_{\max }\left(\mu \mathrm{mol} \mathrm{N} \mathrm{g}{ }^{1} \mathrm{DW} \mathrm{h}^{-1}\right), K_{\mathrm{m}}(\mu \mathrm{M})$ and the affinity for uptake at low concentrations $\left(V_{\max } / K_{\mathrm{m}}\right.$; Healy 1980 ) for surge uptake of ammonium (surge; $V^{-}$). uptake and assimilation of ammonium ( $V^{\text {ass }}$ ) and uptake of nitrate $(V)$ for 6 species of macroalgae. Parameter estimates were obtained by non-linear least squares regression. Numbers are mean values $\pm 95 \%$ confidence intervals. The coefficient of determination $\left(r^{2}\right)$ is also given; all regressions were highly significant $(p<0.001)$

\begin{tabular}{|c|c|c|c|c|c|c|c|c|c|c|c|c|}
\hline & \multicolumn{4}{|c|}{ Surge uptake of ammonium ( $V^{s}$ ) } & \multicolumn{4}{|c|}{ Assimilation of ammonium ( $\left.V^{\text {ass }}\right)$} & \multicolumn{4}{|c|}{ Nitrate uptake (V) } \\
\hline & $V_{\max }$ & $K_{\mathrm{m}}$ & $V_{\max } / K_{\mathrm{m}}$ & $r^{2}$ & $V_{\max }$ & $K_{\mathrm{m}}$ & $V_{\max } / K_{\mathrm{m}}$ & $r^{2}$ & $V_{\max }^{\prime}$ & $K_{\mathrm{mi}}$ & $V_{\max } / K_{m}$ & $r^{2}$ \\
\hline Fucus vesiculosus & $41 \pm 7$ & $21 \pm 10$ & 2.0 & 0.99 & $22 \pm 5$ & $14 \pm 7$ & 1.6 & 0.77 & $8 \pm 1$ & $11 \pm 5$ & 0.7 & 0.91 \\
\hline Codium fragile & $81 \pm 15$ & $25 \pm 12$ & 3.3 & 0.94 & $44 \pm 5$ & $12 \pm 3$ & 3.8 & 0.93 & $9 \pm 1$ & $5 \pm 1$ & 2.0 & 0.92 \\
\hline Chaetomorpha linum & $132 \pm 29$ & $1.3 \pm 12$ & 10.2 & 0.89 & $47 \pm 5$ & $3 \pm 1$ & 13.6 & 0.89 & $30 \pm 5$ & $3 \pm 1$ & 9.9 & 0.95 \\
\hline Cladophora serica & $122 \pm 33$ & $13 \pm 10$ & $9.8<$ & 0.94 & $43 \pm 6$ & $5 \pm 3$ & 9.4 & 0.87 & $17 \pm 2$ & $5 \pm 2$ & 3.5 & 0.84 \\
\hline Ceramium rubrum & $271 \pm 81$ & $29 \pm 21$ & 9.4 & 0.95 & $59 \pm 6$ & $5 \pm 2$ & 12.3 & 0.89 & - & - & - & - \\
\hline Ulva lactuca & $240 \pm 61$ & $21 \pm 16$ & $11.3 c$ & 0.88 & $72 \pm 6$ & $6 \pm 2$ & 12.4 & 0.95 & $20 \pm 3$ & $5 \pm 2$ & 4.5 & 0.86 \\
\hline
\end{tabular}




\section{Uptake rates}

The uptake of ammonium was initially enhanced when $\mathrm{N}$ depleted algae were suddenly exposed to ammonium. Uptake rates are, therefore, represented by 2 sets of uptake kinetics: (1) one representing transiently enhanced uptake (i.e. surge uptake), measured during the first $15 \mathrm{~min}$ after exposure to ammonium, and (2) one representing the uptake rates obtained later than 120 min after exposure (here denoted as the 'assimilation rate'; see Pedersen 1994, McGlathery et al. 1996). The surge uptake probably represents a combination of adsorption of ions onto the plant surface and the absorption of ions into the plant tissue, while assimilation uptake most likely represents the rate of amino acid synthesis within the algae (McGlathery et al. 1996). The rate of surge uptake increased and tended to saturate with increasing substrate concentration among all the algal species examined (Fig. 2), but the kinetic constants exhibited large species-specific variations (Table 2). The maximum rate of surge uptake $\left(V_{\text {max }}^{S}\right)$ ranged 6 -fold, from $41 \mu \mathrm{mol} \mathrm{Ng}^{-1} \mathrm{DW} \mathrm{h}^{-1}$ in Fucus vesiculosus to $271 \mu \mathrm{mol} \mathrm{N} \mathrm{g}^{-1} \mathrm{DW}$ $\mathrm{h}^{-1}$ in Ceramium rubrum. The half-saturation constant $\left(K_{\mathrm{m}}\right)$ ranged from $13 \mu \mathrm{M}$ in Cladophora serica to $29 \mu \mathrm{M}$ in C. rubrum, but all $K_{\mathrm{m}}$ values were characterized by large errors, making inter-specific differences non-significant at the 5\% level. The $V_{\mathrm{max}}: K_{\mathrm{m}}$ ratios for ammonium (i.e. the affinity for ammonium uptake at low substrate concentrations) were higher among the ephemeral algae than for slow-growing species (9 to 11 vs 2 to 3 ; Table 2).

The assimilation rate of ammonium ( $V^{\text {ass }}$ ) also increased and saturated with increasing substrate concentration, but rates were generally 2 - to 5 -fold lower than surge uptake rates at high substrate concentrations (Fig. 2). Maximum assimilation rates ( $V_{\text {max }}^{\text {ass }}$ ) ranged from $22 \mu \mathrm{mol} \mathrm{N} \mathrm{g}^{-1} \mathrm{DW} \mathrm{h}^{-1}$ in Fucus vesiculosus to $72 \mu \mathrm{mol} \mathrm{N} \mathrm{g}^{-1} \mathrm{DW} \mathrm{h}^{-1}$ in Ulva lactuca (Table 2). The half-saturation constants for assimilation were also lower than those for surge uptake, so the $V_{\max }: K_{\mathrm{m}}$ ratios for surge and assimilation uptake remained roughly the same. Identical $V_{\max }: K_{\mathrm{m}}$ ratios of surge and assimilation uptake indicate that the rates of ammonium uptake were not initially enhanced at low substrate concentrations.

We evaluated the potential gain of $\mathrm{N}$ achieved by the algae during surge uptake, by comparing the amounts of $\mathrm{N}$ that could be accumulated in excess of $\mathrm{N}$ assimi- lation during the surge phase at high ammonium concentrations. The $\mathrm{N}$ gained during the surge phase ranged from $9.6 \mu \mathrm{mol} \mathrm{N} \mathrm{g}^{-1} \mathrm{DW}$ in Fucus vesiculosus to 106. $1 \mu \mathrm{mol} \mathrm{g}{ }^{-1}$ DW in Ceramium rubrum (Table 3), and the ephemeral species accumulated in general more $\mathrm{N}$ per unit of biomass than the slow-growing algae. The higher gain by ephemeral algae was, however, balanced by higher $\mathrm{N}$ requirements for growth, and the $\mathrm{N}$ pool accumulated during the surge phase could sup-

Table 3. Role of surge uptake. Amount of ammonium taken up in excess of assimilation uptake during the surge phase $(\mathrm{N}$ gain), and the period of growth at maximum rates that can be supported by the ammonium taken up during the surge phase for 6 different species of macroalgae

\begin{tabular}{|lcc|}
\hline & $\begin{array}{c}\text { N gain } \\
\left(\mu \mathrm{mol} \mathrm{N} \mathrm{g} \text { }^{-1}\right.\end{array}$ & $\begin{array}{c}\text { Growth period } \\
\text { (h) }\end{array}$ \\
\hline Fucus vesiculosus & 9.6 & 4.6 \\
Codium fragile & 18.7 & 4.8 \\
Chaetomorpha linum & 42.6 & 6.0 \\
Cladophora serica & 39.3 & 2.9 \\
Ceramium rubrum & 106.1 & 3.3 \\
Ulva lactuca & 84.0 & 2.6 \\
\hline
\end{tabular}




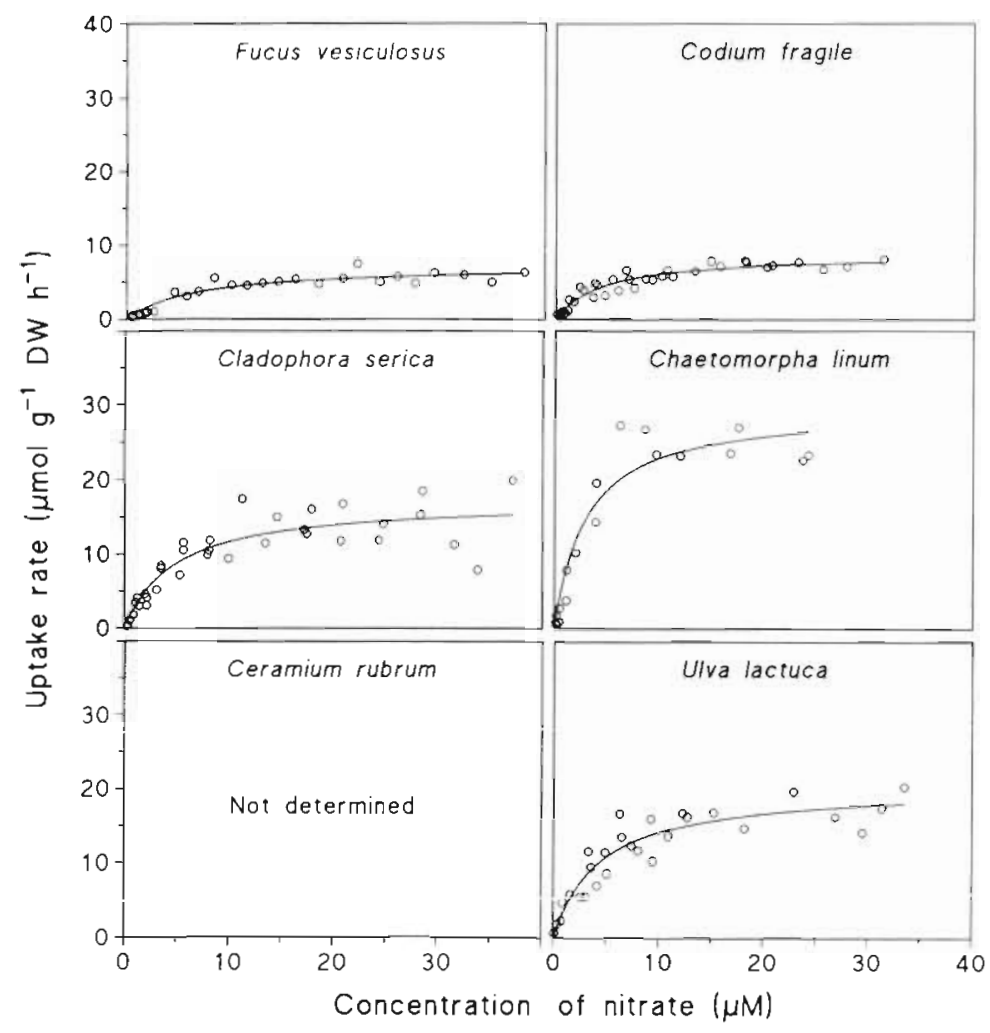

Fig. 3. Uptake rates of nitrate as a function of substrate concentration. Uptake rates (0) were measured later than 60 min after the experiments were initiated to avoid the initial phase of suppressed nutrate uptake exposure to nitrate. The uptake rates of nitrate were, like those of ammonium, hyperbolically related to substrate concentration (Fig 3), but lower than the uptake rates of ammonium (Table 2). As for ammonium, maximum uptake rates of nitrate were related to species-specific differences in maximum growth rate, and maximum uptake rates for Chaetomorpha linum, Ulva lactuca, and Cladophora serica were 3- to 4fold higher than those for Codium fragile and Fucus vesiculosus. The half-saturation constants varied 4 -fold among species, and the ratio of $V_{\text {max }}: K_{\text {m }}$ tended to be highest among the fast-growing algae (Table 2).

The ratio between $V_{\max }$ and the amount of $\mathrm{N}$ required to sustain maximum growth varied substantially among species. Nll macroalgae could potentially take up ammonium and nitrate faster than needed for maximum growth, given that substrate concentrations were high enough, but the slow-growing species had ratios of $V_{\text {max }}$ : $\mathrm{N}$ requirement that were approximately 2-fold higher than for ephemeral species, suggesting that slow-growing species have a higher capacity for taking up $\mathrm{N}$ in excess of immediate demands for growth. port growth for approximately the same period of time for all species (range: from 2.6 to $5.7 \mathrm{~h}$; Table 3 ).

Uptake of nitrate was initially suppressed and was, therefore, taken as the rates measured after the initial lag phase had ceased, usually within 15 to 60 min after

\section{Balance between $\mathrm{N}$ availability and algal growth}

The estimated maximum growth rates ( $\mu^{*}$ max; Table 4 ) were slightly lower than the maximum growth rates estimated from the laboratory experiments ( $\mu_{\max }$

Table 4. Growth kinetics. Predicted values of maximum growth rates $\left(\mu^{*}{ }_{\text {max }}\right)$, half-saturation constants for growth $\left(K_{u}\right)$ and of the substrate concentrations needed to saturate growth $\left(S^{\circ}{ }_{\text {sit }}\right)$ under steady state conditions in 6 different species of macroalgae with either ammonum or nitrate as inorganic $N$ source. Numbers are bias-adjusted bootstrap means with $95 \%$ percentile-based confidence intervals in parentheses

\begin{tabular}{|c|c|c|c|c|c|c|}
\hline Species & $\mu^{*}{ }_{\max }\left(d^{-1}\right)$ & $\begin{array}{c}\text { Ammonium } \\
K_{\mu}(\mu \mathrm{M})\end{array}$ & $S_{\text {:at }}^{*}(\mu \mathrm{M})$ & $\mu^{*}{ }_{\text {indax }}\left(\mathrm{d}^{-1}\right)$ & $\begin{array}{l}\text { Nitrate } \\
K_{\mu}(\mu \mathrm{M})\end{array}$ & $S_{\text {sat }}^{*}(\mu M)$ \\
\hline Fucus vesiculosus & $\begin{array}{c}0.040 \\
(0.032-0.052)\end{array}$ & $\begin{array}{c}0.29 \\
(-0.74-1.51)\end{array}$ & $\begin{array}{c}2.66 \\
(-6.58-13.68)\end{array}$ & $\begin{array}{c}0.038 \\
(0.031-0.048)\end{array}$ & $\begin{array}{c}0.81 \\
(0.02-1.77)\end{array}$ & $\begin{array}{c}7.32 \\
(0.18-15.94)\end{array}$ \\
\hline Codium fragile & $\begin{array}{c}0.083 \\
(0.071-0.095)\end{array}$ & $\begin{array}{c}0.25 \\
(0.00-0.58)\end{array}$ & $\begin{array}{c}2.22 \\
(0.03-5.19)\end{array}$ & $\begin{array}{c}0.074 \\
(0.065-0.086)\end{array}$ & $\begin{array}{c}0.57 \\
(0.36-0.92)\end{array}$ & $\begin{array}{c}5.11 \\
(3.24-8.31)\end{array}$ \\
\hline Chaetomorpha linum & $\begin{array}{c}0.142 \\
(0.136-0.150)\end{array}$ & $\begin{array}{c}0.11 \\
(0.00-0.21)\end{array}$ & $\begin{array}{c}1.00 \\
(0.01-1.91)\end{array}$ & $\begin{array}{c}0.139 \\
(0.134-0.148)\end{array}$ & $\begin{array}{c}0.13 \\
(0.00-0.28)\end{array}$ & $\begin{array}{c}1.18 \\
(0.00-2.49)\end{array}$ \\
\hline Cladophora serica & $\begin{array}{c}0.208 \\
(0.184-0231)\end{array}$ & $\begin{array}{c}0.36 \\
(0.11-0.71)\end{array}$ & $\begin{array}{c}3.28 \\
(0.99-6.40)\end{array}$ & $\begin{array}{c}0.188 \\
(0.157-0.179)\end{array}$ & $\begin{array}{c}0.83 \\
(-0.02-1.77)\end{array}$ & $\begin{array}{c}7.45 \\
(-0.19-15.97)\end{array}$ \\
\hline Ceramium rubrum & $\begin{array}{c}0.299 \\
(0.284-0.317)\end{array}$ & $\begin{array}{c}0.63 \\
(0.07-1.26)\end{array}$ & $\begin{array}{c}5.65 \\
(0.67-11.31)\end{array}$ & - & - & - \\
\hline Ulva lactuca & $\begin{array}{c}0.452 \\
(0.422-0.482)\end{array}$ & $\begin{array}{c}0.75 \\
(0.52-1.10\}\end{array}$ & $\begin{array}{c}6.71 \\
(4.61-9.90\}\end{array}$ & $\begin{array}{c}0.349 \\
(0.322-0.373)\end{array}$ & $\begin{array}{c}1.45 \\
(0.87-2.10)\end{array}$ & $\begin{array}{c}13.02 \\
(7.84-18.89)\end{array}$ \\
\hline
\end{tabular}


Table 1). Mean values of the half-saturation constant for growth $\left(K_{\mu}\right)$ with ammonium as the $N$ source ranged from $0.11,0.25$, and $0.29 \mu \mathrm{M}$ in Chaetomorpha linum. Codium fragile, and Fucus vesiculosus, respectively, to $0.36,0.63$, and $0.75 \mu \mathrm{M}$ in Cladophora serica, Ceramium rubrum, and Ulva lactuca, respectively. $K_{\mu}$ ranged from $0.13 \mu \mathrm{M}$ in Chaetomorpha linum to $1.45 \mu \mathrm{M}$ in Ulva lactuca when nitrate was the $\mathrm{N}$ source. Hence, $K_{\mu}$ tended to increase with increasing maximum algal growth rate, but the mean values have quite wide confidence limits (Table 4 ) because $K_{\mathrm{u}}$ was estimated from several independent factors ( $E q$. 7) each measured with its own error. The ability to convert available DIN in the water into growth through uptake (represented by the $\mu^{*}{ }_{\text {max }}: K_{4}$ ratio) was highest among the ephemeral algae, but the predicted concentrations of ammonium and nitrate needed to saturate algal growth were higher for U. lactuca, C. rubrum and $C$. serica than for $C$. linum, $C$. fragile and $F$. vesiculosus ( $S^{*}$ sali Table 4 ). These results suggest that ephemeral algae are less tolerant of low concentrations of inorganic $\mathrm{N}$.

\section{DISCUSSION}

The ecological success of large, slow-growing macroalgae in nutrient-poor coastal areas could seem paradoxical because the relatively low ratios of surface area to volume $(\mathrm{SA}: \mathrm{V})$ of these species may confer less 'efficient' nutrient uptake. Indeed, absolute rates of $\mathrm{N}$ uptake are higher per unit of biomass and time for thin than for thick algae (Rosenberg \& Ramus 1984, Hein et al. 1995, this study). When rates are expressed per unit of surface area, however, nutrient uptake 'efficiency' of thick algae tends to be higher than for thin species (Hein et al. 1995). The results presented here strongly support the suggestion that potential competitive success among algal species must be evaluated from the ability of their $\mathrm{N}$ uptake rates to meet the requirements for growth (Dugdale 1967, Turpin 1988). Such discussions of size-related algal competition within communities of micro- or macroalgae are often confused by inappropriate comparison of the efficiency of nutrient uptake alone

The present study classifies the thick, slow-growing macroalgae as being at least as efficient as the thin, fast-growing species in exploiting limited $N$ resources to meet their requirements. The variable $N$ requirements among species were caused primarily by differences in growth rates and secondarily by differences in critical $\mathrm{N}$ concentrations. Species-specific maximum growth rates obtained in the laboratory experiments varied 13 -fold and resembled rates measured for the same species in situ during summer (Pedersen \&
Borum 1996). The observed variations in maximum growth rates with changing algal morphology (i.e thin vs thick thallus) agreed with the general pattern found among algae of different size and thallus complexity (e.g. Littler \& Littler 1980. Nielsen \& Sand-Jensen 1990)

The experimentally obtained subsistence $N$ quotas $\left(N_{Q}\right)$ and critical tissue $N$ concentrations $\left(N_{C}\right)$ also tended to change with algal morphology and maximum growth rate. Subsistence quotas and critical tissue $\mathrm{N}$ concentrations resembled data from the literature (e.g. Hanisak 1979, Gordon et al. 1981, Rosenberg et al. 1984, Fujita et al. 1989, Lavery \& McComb 1991). With the exception of Chaetomorpha linum, ephemeral species had slightly higher subsistence cell quotas and critical $N$ concentrations than slow-growing species and, hence, species-specific $N$ requirements to support maximum growth became several-fold larger among fast- than slow-growing macroalgae. This suggests that fast-growing species face a higher risk of $\mathrm{N}$ limitation when exposed to low $\mathrm{N}$ concentrations, unless their requirements are met by proportionally faster N uptake

The uptake experiments confirmed that the ephemeral algae were superior to the slow-growing species in terms of nutrient uptake per unit of biomass and time. The maximum rate of surge and assimilation uptake of ammonjum, the maximum uptake rate of nitrate and the affinity for both ammonium and nitrate were several-fold higher in the 4 ephemeral macroalgae than in the 2 slow-growing species. Such systematic variations in uptake kinetics are related to differences in algal morphology as thin macroalgae take up nutrients faster per unit of biomass than larger species with thick thalli (Rosenberg et al. 1984, Wallentinus 1984, Fujita 1985, Hein et al. 1995). This is because the small species have higher relative surface areas (i.e. SA:V) than large, thick algae, and uptake rates are primarily scaled to the exposed surface area relative to volume or biomass (Rosenberg \& Ramus 1984, Hein et al. 1995)

The 6 algal species all took up ammonium at transiently enhanced rates when suddenly exposed to high ammonium concentrations after a period of $N$ depletion. Surge uptake of ammonium seems to be controlled by small pools of intracellular ammonium, which may exert a negative feedback control on uptake rates as the pools are filled (Pedersen 1994, McGlathery et al. 1996). Initial uptake rates of ammonium are, therefore, enhanced for a short period of time only, thereafter rates are reduced to more constant levels likely controlled by the rates of amino acid synthesis (assimilation). The presence of surge uptake has been suggested to constitute a competitive advantage to ephemeral micro- and macroalgae living under 
low, but fluctuating, $\mathrm{N}$ availability (e.g. Conway \& Harrison 1977. Fujita 1985). Our data show, however, that surge uptake is not a special feature exclusive for ephemeral species.

The: phase of surge uptake was short-lived, typically lasting for 60 to $120 \mathrm{~min}$, and provided an extra uptake and accumulation of $\mathrm{N}$ in the range of 9 to $106 \mu \mathrm{mol} N$ $\mathrm{g}^{-1}$ DW. This short-term $\mathrm{N}$ storage could, however, only support maximum growth for 3 to $6 \mathrm{~h}$ independently of differences in intrinsic maximum growth rates among species. The advantage of faster surge uptake among ephemeral algae was offset by their higher $\mathrm{N}$ requirements. Furthermore, short-term storage of $\mathrm{N}$ gained through surge uptake could only be realized at high DIN concentrations $(>10 \mu \mathrm{M})$ rarely experienced under field conditions. At low, and more natural, concentrations 10 to $10 \mu \mathrm{M}$ DIN in Roskilde Fjord; Pedersen \& Borum 1996), no significant differences appeared between rates of surge and assimilation uptake as reflected by the similar $V_{\max } K_{\mathrm{m}}$ ratios. Hence, surge uptake may not be as ecologically important for algal $\mathrm{N}$ acquisition as formerly suggested in the literature.

Modeling steady-state growth, by combining the kinetics for growth and $\mathrm{N}$ uptake of each algal species, showed that the differences in the ability among species to sustain growth as a function of external $N$ concentrations were small. The half-saturation constants for growth were generally low $\left(K_{\mu}=0.11\right.$ to $0.75 \mu \mathrm{M}$ for ammonium, 0.13 to $1.45 \mu \mathrm{M}$ for nitrate) but comparable to experimentally determined values for other species of macroalgae (DeBoer et al. 1978, Gordon et al. 1981, Rosenberg et al. 1984). The low $K_{\mu}$ values suggest that all the species examined are well suited to sustain high growth rates at low DIN concentrations. The ratio between the half-saturation constants for growth and uptake $\left(K_{\mu} / K_{\mathrm{m}}\right)$ can been used as an index of sensitivity to nutrient stress; the lower $K_{\mu}$ is relative to $K_{\mathrm{m}}$, the higher is the capacity for a given species to grow under low external nutrient concentrations because of variable cell quota (see Turpin 1988 for details). The ratio of $K_{\mu}: K_{\mathrm{m}}$ for ammonium was substantially lower for Fucus vesiculosus, Codium fragile and Chaetomorpha linum 10.022 to 0.033$)$ than for Cladophora serica, Ceramium rubrum and Ulva lactuca (0.076 to 0.127), and the 3 former species should, therefore, be better suited to sustain growth at low external $\mathrm{N}$ concentrations than the latter. According to our calculations of substrate dependent growth, the algal species would become $N$ limited in the following sequence as the availability of DIN decreases: U. lactuca, C. rubrum, $C$. serica, $F$. vesiculosus, $C$. fragile, and finally $C$ linum. Hence, our data suggest that ephemeral algae, with the exception of $\mathrm{C}$. linum, will experience $\mathrm{N}$ limitation at higher DIN concentrations than slow-growing species, making them more sensitive to $N$ stress.
Overall, the present study has demonstrated that slow-growing macroalgae can exploit immediate $\mathrm{N}$ resources through uptake as efficiently as, or even more efficiently than, fast-growing algae. The slow-growing species have, in addition, a higher capacity for utilizing internal $\mathrm{N}$ stores to cover their requirements for growth at low external $N$ availability than the ephemeral macroalgae or phytoplankton (Pedersen \& Borum 1996). In combination, these abilities suggest that plants with inherently low maximum growth rates are better able to sustain maximum (i.e. non-nutrient limited) growth than ephemeral species in areas or seasons of low $\mathrm{N}$ availability. This is consistent with the observed differences in the temporal extent of $\mathrm{N}$ limitation observed among algae of different growth strategy in Roskilde Fjord (Pedersen \& Borum 1996), where ephemeral macroalgae exhibited $\mathrm{N}$ limited growth for longer periods in summer than slow-growing species.

Since species-specific rates of biomass losses are almost directly scaled to intrinsic plant growth rates (Cebrian \& Duarte 1994, Duarte 1995), we assume that the algae best able to sustain maximum growth rates under conditions of $\mathrm{N}$ limitation will have the competitive advantage to become dominant in mixed algal communities. At high and non-limiting $\mathrm{N}$ availability, ephemeral algae will be favored simply because of their high growth rates and will flourish at the expense of more slow-growing species (Sand-Jensen \& Borum 1991, Duarte 1995). At low and potentially limiting $N$ availability, the slow-growing species should be favored, while fast-growing species struggle to balance the continuously high biomass losses. These scenarios agree with the characteristic changes in plant communities described from a broad variety of natural and artificial coastal systems suffering from eutrophication (Borum 1983, Orth \& Moore 1983, Kautsky et al. 1986, Sfriso et al. 1987, Neundorfer \& Kemp 1993, Ménesguen \& Piriou 1995, Taylor et al. 1995, Borum \& Sand-Jensen 1996). Accordingly, we have provided a plausible, functional explanation for the effect of nutrients on the balance among algae of different growth strategy in coastal waters. Although we have primarily compared growth and nutrient kinetics of marine macroalgae, we expect that the functional explanation will be valid for size-related competition among algal species within micro- and macroalgal communities in general

Acknowledgements. This study was supported by a HAV-90 grant from the Danish National Agency of Environmental Protection. We thank K. Sand-Jensen, W. M. Kemp, and 3 anonymous referees for valuable comments, and Birgit Kjøller for technical support during the experiments. Contribution \#1053 from the Freshwater-Biological Laboratory, University of Copenhagen 


\section{LITERATURE CITED}

Borum J (1983) The quantitative role of macrophytes, eplphytes and phytoplankton under different nutrient condl. tions in Roskilde Fjord, Denmark. Proc Int Symp Aquat Macrophytes, Faculty of Science, University of Nijmegen, p $35-40$

Borum J (1996) Shallow waters and land/sea boundaries. In Jorgensen BB, Richardson K (eds) Eutrophication in coastal marine ecosystems. Coast Estuar Stud 52:189-204

Borum J, Sand-Jensen K (1996) Is total primary production in shallow coastal marine waters stimulated by nitrogen loading? Oikos 76:406-410

Cebrian J, Duarte CM (1994) The dependence of herbivory on growth rate in natural plant communities. Funct Ecol 8 . $518-525$

Conway HL, Harrison PJ (1977) Marine diatoms grown in chemostats under silicate or ammonium limitation. IV Transient response of Chaetoceros debilis, Skeletonema costatum and Thalassiosira gravida to a single addition of the limiting nutrient. Mar Biol 43:33-43

DeBoer JA, Guigli HJ, Israel TL, D'Elia CF (1978) Nutritional studies of 2 red algae. I. Growth rate as a function of nitrogen source and concentration. J Phycol 14:261-266

Droop MR (1983) 25 years of algal growth kinetics: a personal view. Botanica Mar 26:99-112

Duarte CM (1992) Nutrient concentration of aquatic plants: patterns across species. Limnol Oceanogr 37:882-889

Duarte CM (1995) Submerged aquatic vegetation in relation to different nutrient regimes. Ophelia 41:87-112

Dugdale RC (1967) Nutrient limitation in the sea: dynamics, identification and significance. Limnol Oceanogr 12 $685-695$

Efron B, Tibshirani R (1986) Bootstrap methods for standard errors, confidence intervals, and other measures of statistical accuracy. Stat Sci 1:54-77

Fujita RM (1985) The role of nitrogen status in regulating transient ammonium uptake and nitrogen storage by macroalgae. J Exp Mar Biol Ecol 92:283-301

Fujita RM, Wheeler PA, Edwards RL (1989) Assessment of macroalgal nitrogen limitation in a seasonal upwelling region. Mar Ecol Prog Ser 53:293-303

Gordon DM, Birch PB, McComb AJ (1981) Effects of inorganic phosphorus and nitrogen on the growth of an estuarine Cladophora in culture. Bot Mar 24:93-106

Hanisak MD (1979) Nitrogen limitation of Codium fragıle sp. tomentosoides as determıned by tissue analysis. Mar Bıol 50:333-337

Harrison PJ, Parslow JS, Conway HL (1989) Determination of nutrient uptake kinetic parameters: a comparison of methods. Mar Ecol Prog Ser 52:301-312

Healy FP (1980) Slope of the Monod equation as an indicator of advantage in nutrient competition. Microb Ecol 5:281-286

Hein M. Pedersen MF, Sand-Jensen K (1995) Size-dependent nitrogen uptake in micro- and macroalgae. Mar Ecol Prog Ser 118:247-253

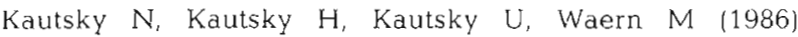
Decreased depth penetration of Fucus vesiculosus (L.) since the 1940's indicates eutrophication of the Baltic Sea. Mar Ecol Prog Ser 28:1-8

Lavery PS, McComb AJ (1991) The nutritional eco-physiology of Chaetomorpha linum and Ulva rigida in Peel Inlet Western Australia. Botanica Mar 34:251-260

Littler MM, Littler DS (1980) The evolution of thallus form and survival strategies in benthic marine macroalgae: field and laboratory tests of a functional form model. Am Nat $116: 25-44$
McGlathery KJ, Pedersen MF, Borum J (1996) Changes in intracellular nitrogen pools and feedback controls on nitrogen uptake in Chaetomorpha hnum (Chlorophyta). J Phycol 32:393-401

Ménesguen A, Piriou JY (1995) Nitrogen loadings and macroalgal (Ulva sp.) mass accumulatıon in Brittany (France). Ophelia 42:227-237

Meyer JS, Ingersoll CG, McDonald LL, Boyce MS (1986) Estimating uncertainty in population growth rates: jackknife vs. bootstrap techniques. Ecology 67:1156-1166

Neundorfer JV, Kemp WM (1993) Nitrogen versus phosphorus enrichment of brackish waters: response of the submerged plant Potamogeton perfoliatus and its associated algal conmunities. Mar Ecol Prog Ser 94:71-82

Nielsen SL, Sand-Jensen K (1990) Allometric scaling of maxlmal photosynthetic growth rate to surface/volume ratio Limnol Oceanoor 35:177-181

Orth RJ, Moore KA (1983) Chesapeake Bay: an unpredicted decline un submerged aquatic vegetation. Science 222:51-53

Pedersen MF (1994) Transient ammonium uptake in the macroalga Ulva lactuca L. (Chlorophytá): nature, regulation, and the consequences for choice of measuring technique. J Phycol 30:980-986

Pedersen MF (1995) Nitrogen limitation of photosynthesis and growth: comparison across aquatic plant communities in a Danish estuary (Roskilde Fjord). Ophelia 41:261-272

Pedersen MF, Borum J (1996) Nutrient control of algal growth in estuarine waters. Nutrient limitation and the importance of nitrogen requirements and nitrogen storage among phytoplankton and species of macroalgae. Mar Ecol Prog Ser 142:261-272

Rosenberg G. Probyn TA, Mann KH (1984) Nutrient uptake and growth kinetics in brown seaweeds: response to continuous and single additions of ammonium. J Exp Mar Biol Ecol 80:124-146

Rosenberg G, Ramus J (1984) Uptake of inorganic nitrogen and seaweed surface area:volume ratios. Aquat Bot 19: $65-72$

Sand-Jensen K, Borum J (1991) Interactions among phytoplankton, periphyton, and macrophytes in temperate freshwaters and estuaries. Aquat Bot 41:137-175

Sfriso A, Marcomini A, Pavonı B (1987) Relationships between macroalgal biomass and nutrient concentrations in a hypereutrophic area of the Venice lagoon. Mar Environ Res 22:297-312

Solórzano L (1969) Determination of ammonia in natural waters by the phenolhypochlorite method. Limnol Oceanogr 14:799-801

Taylor DI, Nixon SW, Granger SL, Bucley BA, McMahon JP, Lin HJ (1995) Responses of coastal lagoon plant communities to different forms of nutrient enrichment-a mesocosm experiment. Aquat Bot 52:19-34

Thomas TE, Harrison PJ (1987) Rapid ammonium uptake and nitrogen interactions in five intertidul seaweeds grown under field conditions. J Exp Mar Biol Ecol 107:1-8

Turpin DH (1988) Physiological mechanisms in phytoplankton resource competition. In: Sandgren CD (ed) Growth and reproductive strategies of freshwater phytoplankton. Cambridge University Press, Cambridge, p 369-387

Twilley RR, Kemp WM, Staver KW, Stevenson JC, Boynton WR (1985) Nutrient enrichment of estuarine submersed vascular plant communities: 1. Algal growth and effects on production of plants and associated communities. Mar Ecol Prog Ser 23:179-191

Wallentinus I (1984) Comparisons of nutrient uptake rates for Baltic macroalgae with different thallus morphologies. Mar B1ol 80:215-225

Submitted: June 12, 1997; Accepted: November 3, 1997

Proofs received from author(s): December 22, 1997 